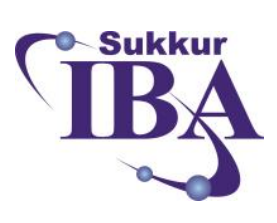

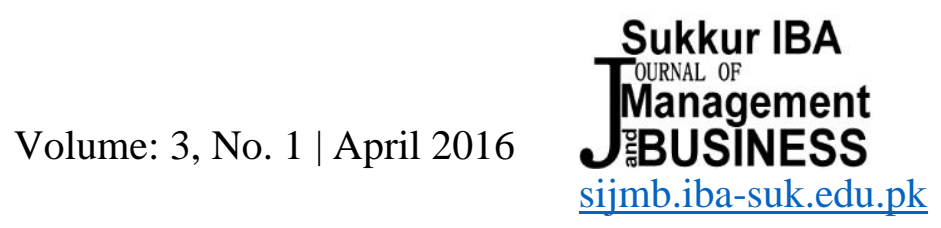

\title{
Co-Integration between Stock Prices and Exchange Rate of Selected SAARC Countries: An Empirical Study
}

\author{
Sumaira Channa ${ }^{* 1}$ \\ MS Scholar, Department of Business Administration, Sukkur Institute of Business \\ Administration \\ Pervaiz Ahmed Memon ${ }^{2}$ \\ Assistant Professor, Department of Business Administration, Sukkur Institute of \\ Business Administration
}

\section{Muhammad Ramzan Kalhoro ${ }^{3}$}

Research Assistant, Office of Research, Innovation \& Commercialization - ORIC, Sukkur Institute of Business Administration

\begin{abstract}
This study examines the relationship between stock prices and exchange rates of three selected SAARC countries including Pakistan, India and Srilanka; using monthly data from period of January 1999 to December 2015. This study employs statistical techniques of Augmented Dickey Fuller (ADF), Phillips Perron (PP), unit root tests, and Johansen's Co-integration test to determine long run equilibrium association ship between stock price indices and exchange rates. The study finds out no Co-integration between the two variables, hence no long run association is existing between them. This finding implies that investors in these markets are having more opportunities for diversifying their portfolios. However, using Granger Causality and impulse response tests, it finds significant short-run feedback effects, as stock prices Granger cause exchange rates in case of Pakistan and unidirectional causality flows from exchange rates to stock prices in case of Srilanka but no proof of causality running in either direction in case of India. Hence the findings for Pakistan and Srilanka have crucial policy implications.
\end{abstract}

Keywords: Exchange rate, Stock price indices, Johansen Co-integration, Granger Causality, Impulse Response, SAARC countries.

https://doi.org/10.30537/sijmb.v3i1.138

${ }^{*}$ Corresponding Author

${ }^{1}$ sumaira.channa@hotmail.com

2 pervaiz@iba-suk.edu.pk

3 ramzan.kalhoro@iba-suk.edu.pk

SIJMB | E-ISSN: 2410-1885; P-ISSN: 2313-1217 @ 201682 Sukkur Institute of Business Administration - All rights reserved 


\section{Introduction}

The South Asian Association for Regional Co-operation (SAARC) is an economic organization comprising of eight countries that are located in the South Asia namely; Pakistan, India, Srilanka Bangladesh, Bhutan, Maldives, Afghanistan and Nepal. Development and investment carry lot of importance in these countries (Devanthran, 2009). These countries have witnessed financial market reforms of early 90s, Asian currency crisis of 1997-98, and arrival of floating exchange rate in 1970s. All these developments suggest the importance of understanding association ship between stock prices and foreign exchange rate in these regions.

Stock market, being an important component of capital market, plays an essential role in economic development of the country. When capital market is efficient, it can enhance growth of the economy by maintaining financial sector and providing good investment channels, which play very necessary role whilst engaging domestic and foreign investors (Okoli, 2012).

When there is high exchange rate, home currency depreciates and stock prices decrease, which increases risk and has negative consequences on economy. When a currency depreciates in relation to the other currencies, imports become expensive. This means our currency will buy less of foreign currency; hence it will be difficult to purchase foreign goods. One of the biggest disadvantages of high exchange rate is that it can lead to trade deficits. If exchange rates are stable it will leave a good impact on our economy and benefits businesses in a way that it reduces the risk factors for businesses as well as for investors (Ahmed, 2015).

When there is fluctuation in exchange rate; it will affect stock prices (Halttunen, Masson, \& Branson, 1977). High stock prices will result in increased flow of foreign capital. Hence, fall in share prices will be leading to decrease in wealth of company which will lead country's wealth to diminish (Meese, Rogoff, \& Kenneth, 1983);(Ghartey, 1998); and (Hasan, Javed, \& Tariq, 2009).

The investors, before making investment, remain vigilant and look at the stock markets performance by noticing stock market index. The stock market index provides us with a yardstick to measure the individual portfolios' performance and it also helps investors with predicting future market trends. The performance of stock market can be measured by observing changes in stock market index that is also affected by various different factors which include social factors, macroeconomic, and political factors.

The rise and fall in the prices of stocks is a crucial mechanism of economies for corporations, policy makers, researchers and investors etc. This rise and fall in prices of stocks is maily determined by Demand and supply (Market forces). The stock price is fixed when supply is equal to demand (Muhammad \& Suleman, 2014). When there

SIJMB | P-ISSN: 2313-1217 E-ISSN: 2410-1885 @ 201683 Sukkur Institute of Business Administration V.3, No.1 | Apr 16 
is change in stock market index it can create disturbance in the exchange rate and other macroeconomic factors (Issahaku \& Haruna, 2013).

Despite many investigations, the association between stock prices and exchange rates has remained inconclusive theoretically as well as empirically. Traditional approach theory depicts that there is interrelationship between stock prices and exchange rate and causal relationship runs from exchange rates to stock prices Umer, Sevil, and Kamişli Moreover, the relationship between these two variables is positive. This theory proposes that depreciation in domestic currency gives room to the local firms and these firms become more competitive due to increase in their exports increase which leads to rise in stock prices. On second side, Portfolio Balance Approach suggests that there is negative association between these two variables and causal association-ship runs from stock prices to exchange rates. This theory postulates that individual investors hold local and foreign assets along with money. When there is rise in domestic stock prices then individuals rush to have local (domestic) stock and want to sell foreign stock. Obviously, due to the reason, domestic money demand increases which leads to increase in domestic currency value hence exchange rate (domestic price of foreign currency) decreases (Aydemir \& Demirhan, 2009); (Granger, Huang, \& Yang, 1998); (N. Muhammad, Rasheed, \& Husain, 2002).

Another way through which stock prices may change exchange rates is outflow and inflow of foreign capital. Due to increase in share prices the domestic investors' wealth rises that will in turn swells money demand and hence it also increases interest rates. This increase in interest rates attracts foreign capital which ultimately appreciates the domestic currency (Tourani-Rad, Liu, \& Shrestha, 2008). Besides that, a market may come under the influence of both these models/approaches. If this situation prevails in the market then feedback trend appears in the market (Granger et al., 1998).

In addition to Traditional Approach and Portfolio Approach model, another model i.e. Asset Market Approach has also been discussed in the literature (N. Muhammad et al., 2002); (Tourani-Rad et al., 2008). According to this approach, there is no linkage between exchange rates and stock prices because exchange rate and stock prices movements may be driven by various factors. Hence there may be no association ship between exchange rates and stock prices.

The present study adds to literature by analyzing practical association between exchange rates and stock prices of SAARC countries. The specific objective of this study is to empirically investigate Co-integration between Stock prices and Exchange rates of SAARC countries.

Some studies have already been conducted to investigate the relationship between exchange rates and stock prices of different economies but still there is room to investigate such relationship using Co-integration analysis in a different context.

SIJMB | P-ISSN: 2313-1217 E-ISSN: 2410-1885 @ 201684 Sukkur Institute of Business Administration V.3, No.1 | Apr 16 
Furthermore, existing studies provide conflicting results regarding the relationship between stock prices and exchange rates. This study is also making contribution in this field as it is one of the earlier studies in context of SAARC countries.

The findings of this study are crucial to investors for making short run decisions, as they need to keep in mind the relationship between the two variables. Since the investors are always looking for earning good returns with less risk, so this study, examining the Co-integration between stock market indices of SAARC countries and exchange rates, may be helpful to them in portfolio diversification decision. If stock market and exchange rates are found highly co-integrated with each other, then the investors will not be getting good benefit of diversifying their portfolios.

The remaining paper is organized as follows. Section 2 discusses literature review; section 3 describes data and research methodology. Results and discussion are given in section 4 . Finally, section 5 draws the conclusion and recommendations.

\section{Literature Review}

An ample literature is available that specifically enlightens the influence of Stock prices on exchange rates. The linkage between exchange rate movements and stock market prices has been defined in context of two portfolio models of exchange rate in an economy. One is the "Flow Oriented Model" (FOM) by (Dornbusch \& Fischer, 1980) and (Gavin, 1989), while the other one is "Stock-Oriented Model" (SOM) by (Frankel, 1983) and (Branson, 1983). "Flow Oriented Model" depicts that when there is change in exchange rates it causes change in stock prices with a negative correlation. Exchange rate fluctuations have impact on trade balance of an economy and also the output level of firms. Ups and downs in share price in stock market also influence aggregate demand, which in turn affects wealth. Decrease in stock prices diminishes wealth of investors and furthermore it decreases the demand for money along with currency depreciation (Gavin, 1989).

While Stock-Oriented model suggests that change in stock prices affects exchange rates with a positive correlation. In this model linkage is defined through capital accounts of country. This model states that exchange rate is equal to supply and demand for securities (including bonds and stocks). Therefore, the currency fluctuations have a significant impact on stock price fluctuations. Hence, stock price movements may influence the exchange rate movements.

Franck and Young (1972) have explored the relation between exchange rate and stock prices. They found that there is no significant integration between exchange rate and stock prices. Aggarwal (2003) has made an attempt to explore the dynamic relationship between exchange rate of Dollar and the stock prices indices of US. They report positive significant integration between variables. Later on Aggarwal (2003) results are reconfirmed by the attempts made by (Giovannini \& Jorion, 1987).

SIJMB | P-ISSN: 2313-1217 E-ISSN: 2410-1885 @ 201685 Sukkur Institute of Business Administration V.3, No.1 | Apr 16 
Soenen and Hennigar (1988) study the association between U.S. stock market prices and exchange rates of 15 countries. The findings of this study suggest that there is negative but statistically significant association between exchange rate and stock prices.

Smyth and Nandha (2003) investigated the relationship between stock prices and exchange rates in four South Asian countries including Pakistan, India, Bangladesh, and Sri Lanka on daily data from 1995 to 2001 applying Engle-Granger and Johansen's cointegration techniques. They do not explore any long run association between the two variables for four countries. Using Granger causality test they also conclude that exchange rates Granger cause the stock prices in Sri Lanka and India but for Pakistan and Bangladesh they report no evidence of causality running in either direction.

Phylaktis and Ravazzolo (2005) examine short run and long run association-ship between exchange rates and stock prices using monthly data from 1980 to 1998 for Hong Kong, Malaysia, Indonesia, Philippines, Singapore and Thailand, using Cointegration technique and Granger causality test. They report that stock prices and exchange rates are positively related and US stock price is the causal factor which acts as a channel that links the exchange rates of five countries to their stock market indices.

Yau and Nieh (2006) use monthly data of Japan and Taiwan from 1991 to 2005 to study the relationship among Japan and Taiwan prices of stocks and Yen /NTD exchange rates. They apply Granger causality test and found bi-directional causality between the stock prices of Japan and Taiwan but no significant causal association between Yen NTD exchange rate and the stock prices of Taiwan and Japan has been found. From the Johansen method of co-integration it is concluded that no long run association among the three variables.

Pan, Fok, and Liu (2007) use Johansen co-integration test and Granger causality to explore the linkages between exchange rates and stock prices using daily data from 1988 to 1998 for seven Asian countries namely Hong Kong, Singapore, Japan, Malaysia, Taiwan, Korea, and Thailand. They conclude that during the Asian financial crisis period, there is no long run stable association between exchange rates and stock prices. For Japan, Hong Kong, Malaysia and Thailand there exists a significant causal association between exchange rates and stock prices before the 1997. During the Asian financial crisis period they find causal relationship from exchange rates to stock prices for all countries except Malaysia.

Tourani-Rad et al. (2008) examines the relationship between nominal exchange rates and stock prices using weekly data of seven years (from January 1995 to December 2001) of the Hong Kong economy. Granger Causality and Johansen Co-integration tests are performed. The key findings of their study is that in the short run, causality runs from exchange rate to stock prices whereas, there is no long run relationship between the said variables.

SIJMB | P-ISSN: 2313-1217 E-ISSN: 2410-1885 @ 201686 Sukkur Institute of Business Administration V.3, No.1 | Apr 16 
Lee, Doong, and Chou (2011) explores the dynamic relationship between stock prices and exchange rates in the G-7 countries (France, Canada, Italy, Germany, Japan, USA and UK) using daily data from 1993-1996. This study uses Johansen maximum likelihood method and Engle-Granger of co- integration. Results reveal that there is no long run association between exchange rates and stock prices for all of G-7 countries.

Umoru and Asekome (2013) report positive co-integration between exchange rate and stock prices in Nigerian Stock market. The prime findings using the Granger Causality test shows bi-directional relationship between exchange rate and stock prices.

Yang, Tu, and Zeng (2014) study the relationship between exchange rates and stock returns using daily data from 1997 to 2010 for countries namely Indonesia, Malaysia, India, Japan, Korea, the Philippines, Singapore, Taiwan and Thailand. They apply Granger causality test and report that during the Asian financial crisis in all the countries, except Thailand, there are feedback relations between exchange rates and stock prices and specifically in Thailand, stock returns lead exchange rates. The causal effects are heterogeneous across different quantiles and different periods and most of the foreign exchange markets and stock markets are correlated negatively.

Given the inconclusiveness and contradictory findings of earlier studies regarding the relationship of exchange rate and stock price index this study hypothesize that:

$H_{0}:$ There is no Co-integration between Stock prices index and exchange rate in SAARC Countries.

$H_{1}$ : There is Co-integration between Stock prices index and exchange rate in SAARC countries.

\section{Data \& Methodology}

3.1. Data Description

The study uses monthly data for exchange rate and stock price indices of three SAARC countries namely; Pakistan, India and Sri Lanka, from period of January 1999 to December 2015. This study is confined to only these three SAARC countries because of the unavailability of data for other SAARC countries. Stock price index data of KSE100 index from Pakistan, S\&P BSE SENSEX index for India, and for Srilanka Colombo all share prices index have been used. Data for these indices and exchange rates have been obtained from Bloomberg Terminal. The exchange rates data is defined in terms of units of domestic currency for each country and have been taken in terms of US dollars. In this study all the variables are converted into natural logarithms form.

\subsection{Methodology}

The study uses time series data to explore Co-integration between Exchange rate and stock market indices of three selected SAARC countries. Time Series data has property

SIJMB | P-ISSN: 2313-1217 E-ISSN: 2410-1885 @ 201687 Sukkur Institute of Business Administration V.3, No.1 | Apr 16 
of non-stationarity. The major issue with non-stationary data is that any statistical results we get from running the regression might be spurious. Hence, it must follow the time series properties like the variable should be stationary. A data is said to be stationary if it's mean, variance, and covariance remain the same or constant over time no matter at what point we measure them. The most famous and widely used test for the stationarity of data is unit root testing. If unit root is present; it shows the data is non-stationary (Brooks, 2008). Different tests are available to check the existence of the unit root problem both at levels and at their 1st difference, to explore order of integration. This study uses Augmented Dickey Fuller (ADF) and Phillips-Perron (PP), tests to determine the stationary nature of the series.

In order to employ the co-integration analysis, the Johansen and Juselius (1990) or the Johannisson (1991) can be used. JJ procedure could determine more than one possible co-integrating vectors. This study has employed Co-integration analysis to explore the equilibrium long run relationship between exchange rates and stock prices. If there is long run association between variables, it means the variables are co-integrated. The Johansen and Juselius (1990) procedure depends on estimates of maximum likelihood and it provides Trace Value of test statistics and maximum Eigen Value for finding or detecting number of co-integrating vectors. This approach gives framework for cointegration test in the situation of (VAR) Vector Autoregressive Approach in Johansen procedure and is explained as under:

$$
x_{t}=A_{0}+\sum_{j=1}^{k} A_{j} x_{t-j}+\varepsilon_{t}
$$

Where it is supposed that $A_{o}=(n \times 1)$ vector of constants, $x t$ is $(n \times 1)$ vector of nonstationary

1(1) variable, $\mathrm{k}=$ number of lags, $\mathrm{A} \mathrm{j}=(\mathrm{n} \times \mathrm{n})$ coefficient matrix.

The causality test determines that the current or lag value of one variable causes another variable. Granger causality test is used when all the series are stationarity. In Granger causality test selection of lag length is very important. To select appropriate lag length this study uses Akaike information criteria. This test proposes the null hypothesis rejection showing, there is causal association between series against the alternative hypothesis that there is no causal association between series.

\section{Results and Discussion}

The findings from descriptive statistics, Augmented Dickey Fuller (ADF), PhillipsPerron (PP), unit root tests, Johansen's Co-integration analysis, Granger Causality and impulse response tests are presented and discussed in this section.

SIJMB | P-ISSN: 2313-1217 E-ISSN: 2410-1885 @ 201688 Sukkur Institute of Business Administration V.3, No.1 | Apr 16 
Sumaira et al. / Co-Integration between Stock Prices and Exchange Rate of Selected SAARC Countries - An Empirical Study

\subsection{Descriptive Statistics}

The descriptive statistics for variables namely, exchange rate and stock price indices of three SAARC countries are shown in Table 1. The value of kurtosis and skewness reveals the lack of symmetry in distribution. As a general rule, if value of kurtosis and skewness are between 0 and 3 correspondingly, then distribution is called as normally distributed. The value of standard deviation indicates that stock price indices of Pakistan, India and Srilanka are relatively more volatile as compared to exchange rates for these countries.

Table 1: Descriptive Statistics

\begin{tabular}{lllc}
\hline & Pakistan & India & Srilanka \\
Stock Market Index & LKSE & LBSESENSEX & LCSE \\
\hline Mean & 8.8744 & 9.1958 & 7.6591 \\
Maximum & 10.4840 & 10.2874 & 8.9616 \\
Minimum & 6.8311 & 7.9415 & 6.0004 \\
Std. Deviation & 1.0271 & 0.7362 & 0.9544 \\
Skewness & -0.4229 & -0.2853 & -0.2609 \\
Kurtosis & 2.0717 & 1.5727 & 1.7432 \\
JarqueBera & 13.3417 & 19.9833 & 21.3045 \\
Probability & 0.00126 & 0.00004 & 0.0004 \\
Exchange rate & & & \\
Mean & 4.2655 & 3.8765 & 4.6570 \\
Maximum & 4.6865 & 4.1997 & 4.9651 \\
Minimum & 3.9029 & 3.6718 & 4.2319 \\
Std. Deviation & 0.2389 & 0.1282 & 0.1745 \\
Skewness & 0.3335 & 0.9923 & -0.6287 \\
Kurtosis & 1.5599 & 3.0915 & 2.9934 \\
JarqueBera & 21.3046 & 33.387 & 13.373 \\
Probability & 0.0000 & 0.0000 & 0.0012 \\
& & & \\
Observations & 203 & 203 & 203 \\
\hline
\end{tabular}

\subsection{Unit root test results}

It is crucial to test stationarity of time series data for moving towards Co-integration test and to establish long run relationship. This study uses two different tests, Augmented Dickey-Fuller (ADF) and Phillips Perron (PP) tests to find out the stationarity of data series. The test results reveal that all the series are non-stationary at levels. However, whilst taking the 1 st difference, these variables become stationary at $1 \%, 5 \%$ and $10 \%$ levels respectively. Thus all these stationary tests indicate that all the series are integrated in order of I (1). The findings are reported in Table 2.

SIJMB | P-ISSN: 2313-1217 E-ISSN: 2410-1885 @ 201689 Sukkur Institute of Business Administration V.3, No.1 | Apr 16 
Sumaira et al. / Co-Integration between Stock Prices and Exchange Rate of Selected SAARC Countries - An Empirical Study

\begin{tabular}{|c|c|c|c|c|c|c|c|c|}
\hline \multirow{2}{*}{ Country } & At level & \multicolumn{7}{|c|}{ Table 2: Unit Root Test Statistics for Stationarity } \\
\hline & Variables & $\frac{\underline{\mathrm{t}-}}{\underline{\text { Statist }}}$ & $\underset{\text { value }}{\mathrm{P}-}$ & $\begin{array}{l}\underline{\text { Decisi }} \\
\underline{\text { on }}\end{array}$ & $\underline{\mathrm{t}-\text { Statistic }}$ & $\begin{array}{l}\underline{\mathrm{P}-} \\
\underline{\mathrm{valu}} \\
\underline{\mathrm{e}}\end{array}$ & $\frac{\text { Decisi }}{\underline{\text { on }}}$ & $\begin{array}{l}\text { Order of } \\
\text { Integrat } \\
\text { ion }\end{array}$ \\
\hline \multirow{3}{*}{ Pakistan } & \multicolumn{8}{|c|}{$\begin{array}{l}\text { ADF Unit Root Test } \\
\text { (Null Hypothesis: Variable has a unit root) }\end{array}$} \\
\hline & LKSE 100 & -1.353 & 0.605 & $\begin{array}{l}\text { Unit } \\
\text { Root }\end{array}$ & $-2.876 * *$ & 0.000 & Stationary & $\mathrm{I}(1)$ \\
\hline & LE.RPKR & -0.534 & 0.881 & $\begin{array}{l}\text { Unit } \\
\text { Root }\end{array}$ & $-3.463 *$ & 0.000 & Stationary & $\mathrm{I}(1)$ \\
\hline India & LSENSEX & -0.853 & 0.801 & $\begin{array}{l}\text { Unit } \\
\text { Root }\end{array}$ & $-2.574 * * *$ & 0.000 & Stationary & $\mathrm{I}(1)$ \\
\hline \multirow{3}{*}{ Srilanka } & LE.RIND & -0.103 & 0.947 & $\begin{array}{l}\text { Unit } \\
\text { Root }\end{array}$ & $-3.463 *$ & 0.00 & Stationary & $\mathrm{I}(1)$ \\
\hline & $L C S E$ & -0.697 & 0.844 & $\begin{array}{l}\text { Unit } \\
\text { Root }\end{array}$ & $-2.876 * *$ & 0.00 & Stationary & $\mathrm{I}(1)$ \\
\hline & LE.RSRI & -1.770 & 0.395 & $\begin{array}{l}\text { Unit } \\
\text { Root }\end{array}$ & $-2.574 * * *$ & 0.00 & Stationary & $\mathrm{I}(1)$ \\
\hline \multirow{3}{*}{ Pakistan } & \multicolumn{8}{|c|}{$\frac{\text { PP Unit Root Test }}{\text { (Null Hypothesis: Variable has a unit root) }}$} \\
\hline & LKSE 100 & -1.348 & 0.607 & $\begin{array}{l}\text { Unit } \\
\text { Root }\end{array}$ & $-3.463 *$ & 0.000 & Stationary & $\mathrm{I}(1)$ \\
\hline & LE.RPKR & -0.456 & 0.896 & $\begin{array}{l}\text { Unit } \\
\text { Root }\end{array}$ & $-2.876^{* *}$ & 0.000 & Stationary & $\mathrm{I}(1)$ \\
\hline India & LSENSEX & -0.918 & 0.781 & $\begin{array}{l}\text { Unit } \\
\text { Root }\end{array}$ & $-2.876 * *$ & 0.000 & Stationary & $\mathrm{I}(1)$ \\
\hline \multirow{5}{*}{ Srilanka } & L E.RIND & -0.224 & 0.932 & $\begin{array}{l}\text { Unit } \\
\text { Root }\end{array}$ & $-2.876 * *$ & 0.000 & Stationary & $\mathrm{I}(1)$ \\
\hline & $L C S E$ & -0.769 & 0.825 & $\begin{array}{l}\text { Unit } \\
\text { Root }\end{array}$ & $-2.574 * * *$ & 0.000 & Stationary & $\mathrm{I}(1)$ \\
\hline & L E.RSRI & -1.708 & 0.426 & $\begin{array}{l}\text { Unit } \\
\text { Root }\end{array}$ & $-3.463 *$ & 0.000 & Stationary & $\mathrm{I}(1)$ \\
\hline & \multicolumn{8}{|c|}{ Test critical values (MacKinnon, 1996) } \\
\hline & $\begin{array}{l}1 \% \\
-3.463\end{array}$ & & & $\begin{array}{l}5 \% \\
-2.876\end{array}$ & & & $\begin{array}{l}10 \% \\
-2.574\end{array}$ & \\
\hline
\end{tabular}

Note: $* * *$ and $* * *$ represent significant at $1 \%, 5 \%$ \& $10 \%$ significance level.

The above table shows that, the test statistic value of stock price indices and exchange rate for three countries i.e. Pakistan, India and Srilanka at levels are greater than the critical values at $1 \%, 5 \%$ and $10 \%$ respectively, meaning that we cannot reject the null hypothesis. So it can be concluded that all these variables are non-stationary at levels and are stationary at $1^{\text {st }}$ difference. It is clear from the graphical representation given in (Appendix.1), which shows the trend on exchange rates and stock price indices for said three countries are nonstationary while taking their first difference they become

SIJMB | P-ISSN: 2313-1217 E-ISSN: 2410-1885 @ 201690 Sukkur Institute of Business Administration V.3, No.1 | Apr 16 
Sumaira et al. / Co-Integration between Stock Prices and Exchange Rate of Selected SAARC Countries - An Empirical Study

stationary. As a general rule if p-value is less than $5 \%$ so we can reject the null hypothesis and if $\mathrm{p}$-value is greater than $5 \%$ then we cannot reject the null hypothesis.

\subsection{Co-integration Analysis}

The stationarity analysis findings reveal that, the variables are integrated in same order, so the present study employs the (Johansen \& Juselius, 1990) (JJ) maximum likelihood test. The purpose is to check whether there is co-integration or whether long run relationship exists among the variables. This technique is suitable to use if all the variables are integrated in same order.

Briefly defined, a set of factors or variables is called to be co-integrated if they are individually non-stationary and integrated in the same order, but their linear combination becomes stationary (Ibrahim, 2003). The results of Co-integration analysis test are presented below and they show that the trace test statistics rejects the null hypothesis of $r \leq 0$ against the alternative $r \geq 1$ at $5 \%$ significance level.

The first step in Co-integration analysis is suitable lag selection for variables. For selection of suitable lag length, in this study the lag value is chosen on the basis of VAR statistics by the confirmation of Akaike Information Criteria (AIC). An AIC criterion suggests selection of lag length of 4 for Pakistan. For India it implies suitable lag length of 1 , whereas for Srilanka it reveals value of lag length of 1 .

In order to determine the number of Co-integrating vectors, Trace statistic and Maximal Eigen value tests have been used. The results suggest evidence for the presence of no co-integrating vectors in model. The results are given below in table.3.

Table 3: Johansen and Juselius Co-integration Test:

\begin{tabular}{llllllllll}
\hline Variables & Trace Statistic & $\begin{array}{l}0.05 \\
\text { Critica } \\
\text { 1 value }\end{array}$ & $\begin{array}{l}\text { Prob. } \\
* *\end{array}$ & $\begin{array}{l}\text { Max-Eigen } \\
\text { Statistic }\end{array}$ & $\begin{array}{l}0.05 \\
\text { Critica } \\
\text { 1 value }\end{array}$ & $\begin{array}{l}\text { Prob.* } \\
*\end{array}$ \\
\hline Pakistan & None & 4.996 & 15.495 & 0.809 & None & 4.768 & 14.265 & 0.771 \\
& At most 1 & 0.227 & 3.841 & 0.633 & At most 1 & 0.227 & 3.841 & 0.633 \\
India & None & 2.858 & 15.495 & 0.973 & None & 2.774 & 14.265 & 0.961 \\
& & & & & & & & & \\
St most 1 & 0.085 & 3.841 & 0.771 & At most 1 & 0.085 & 3.841 & 0.771 \\
& None & 10.015 & 15.495 & 0.279 & None & 7.699 & 14.265 & 0.410 \\
& At most 1 & 2.316 & 3.841 & 0.128 & At most 1 & 2.316 & 3.841 & 0.128
\end{tabular}

Trace test and Max-Eigen test indicates no Co-integrating equ. at the 0.05 percent Prob. level * denotes the rejection of hypothesis at $0.05 \%$ Prob. level.

SIJMB | P-ISSN: 2313-1217 E-ISSN: 2410-1885 @ 201691 Sukkur Institute of Business Administration V.3, No.1 | Apr 16 
The findings of both trace statistic and Maximum- Eigen statistic are reported in the Table 4. These both tests, Trace and Maximum Eigen-statistic identified no cointegrating equations at 5\% significance level. Hence it confirms that long run equilibrium association between the variables does not exist and indicates that, null hypothesis cannot be rejected which is no co-integrating relationship at $0.05 \%$ significance level.

It is very common for estimated test statistic that it can show different results (Gan, Lee, Yong, \& Zhang, 2006). The inferences are based on the fact or evidence that calculated value of Trace statistic and Maximum-Eigen statistic is less than their Critical values at 5\% significant level (Rahman \& Mustafa, 2008). Trace statistic and maximum Eigen statistic value is less than the critical values, therefore the null hypothesis cannot be rejected and it is concluded that, there is no Co-integration or no long run equilibrium association between the variables under study. The results of this study are consistent with the findings of the previous studies conducted by, (Bahmani-Oskooee \& Sohrabian, 1992); (Lee et al., 2011); (Pan et al., 2007); (Smyth \& Nandha, 2003); (Tourani-Rad et al., 2008). All of these studies do not find any long run equilibrium association between the two variables.

In the absence of co-integration between variables, the Granger causality test and impulse response analysis are employed within vector auto regression (VAR) framework and Granger causality test is based on Granger et al. (1998) method. The Granger technique seeks to determine how much of a variable $Y$ can be best defined by the past values of $\mathrm{Y}$ variable and by adding the lagged values of another variable $\mathrm{X}$. Can it improve the explanation, whereas impulse response is used to identify the response and behavior of stock prices to the shocks in relation to exchange rate fluctuations and vice-versa? Granger causality test identifies the impact of each variable's shock on the other.

Granger causality test determines two things; one is to determine uni or bilateral causality and second one to find out that which variable cause the other variable. In Granger causality test optimal lag selection is very essential. For this purpose Akaike Information Criterion (AIC) is used. Here the optimal lag length is 2. The findings of pair wise Granger causality is given in table 4.

Table 4: Granger causality test Results

\begin{tabular}{lllll}
\hline Countries & \multicolumn{2}{l}{ Null Hypothesis/Results } & $\underline{\text { F- Statistic }}$ & Probability \\
\hline Pakistan & LKSE does not Granger Cause & 5.36746 & 0.0054 \\
& LERPKR & & \\
& LERPKR does not Granger Cause & 2.34358 & 0.0987 \\
& LKSE
\end{tabular}

SIJMB | P-ISSN: 2313-1217 E-ISSN: 2410-1885 @ 201692 Sukkur Institute of Business Administration V.3, No.1 | Apr 16 
Sumaira et al. / Co-Integration between Stock Prices and Exchange Rate of Selected SAARC Countries - An Empirical Study

\begin{tabular}{llll}
\hline India & $\begin{array}{l}\text { LSENSEX does not Granger Cause } \\
\text { LERIND }\end{array}$ & \\
& $\begin{array}{l}\text { LERIND does not Granger Cause } \\
\text { LSENSEX }\end{array}$ & 0.95055 & 0.3275 \\
Srilanka & $\begin{array}{l}\text { LCSE does not Granger Cause } 1.24689 \\
\text { LERSRI }\end{array}$ & 0.2897 \\
& $\begin{array}{l}\text { LERSRI does not Granger Cause } 3.44612 \\
\text { LCSE }\end{array}$ & 0.0338 \\
\hline Granger causality test Results - Cont.
\end{tabular}

Table (4) shows the Granger Causality test results for three countries. Granger Causality has been applied on variables. The data are non-stationary at levels and are converted to 1 st difference in order to make it stationary to test lead lag relationship. The analysis of Granger Causality reveals that there is no causality between the selected variable in case of India. In case of Pakistan analysis implies significant flow from stock prices to exchange rate and it is unidirectional. There is also significant unidirectional flow from exchange rate to stock price in case of Srilanka.

\subsection{Impulse Response}

The impulse response analysis indicates the response of the stock price to a one standard deviation shock to their exchange rates for three countries are presented in figure 1, 2 and 3 for Pakistan, India and Srilanka. The impulse response analysis are modelled using the generalized impulses as explained by (Pesaran \& Shin, 1998).

The impulse response analysis for Pakistan, show that Stock prices respond negative and significant to the shocks inferred by the exchange rate for the few years then it becomes insignificant. For India stock market prices responds negatively for initial years and then it becomes positive and significant to the shocks induced by the exchange rate. The impulse response patterns for Srilanka indicates significant positive response to the shocks induced by the exchange rate. Impulse response shocks induced by stock prices and exchange rate for three countries are different.
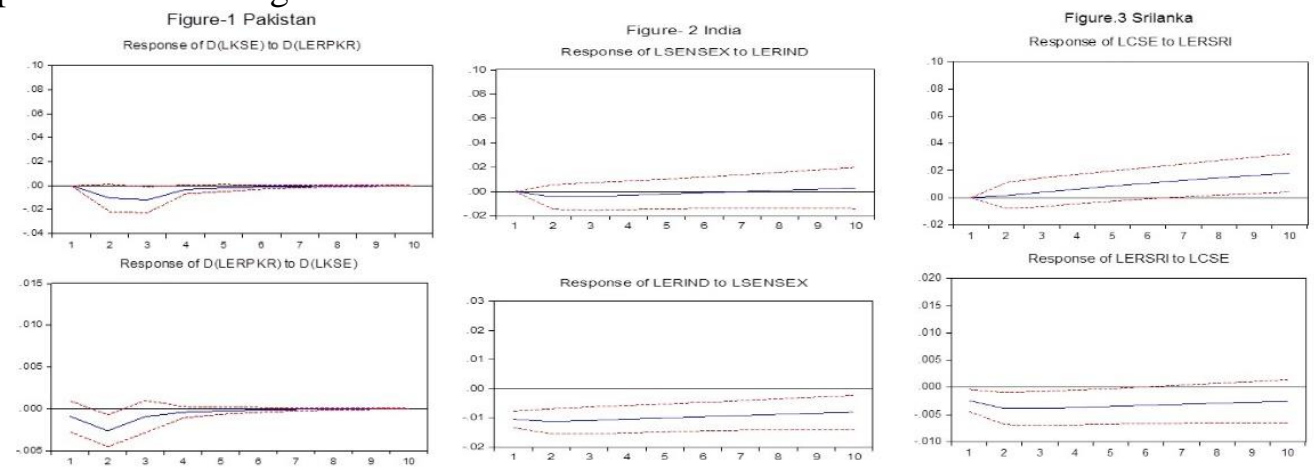

SIJMB | P-ISSN: 2313-1217 E-ISSN: 2410-1885 ( 201693 Sukkur Institute of Business Administration V.3, No.1 | Apr 16 


\section{Conclusion and Recommendation}

This study aims to examine Co-integration between stock prices and exchange rates of three SAARC countries namely Pakistan, India and Srilanka. Augmented Dickey-Fuller (ADF) and Phillips-Perron (PP), Unit root tests, Johansen's Co-integration tests, Granger Causality and impulse response tests have been employed using monthly data from period of January 1999 to December 2015. Findings of this study reveal that stock prices and exchange rates are not co-integrated and therefore no long run equilibrium association existing between them. This means that stock prices and exchange rates do not fluctuate combinely in long run.

Furthermore, even though there is no long-run associationship between stockprices and exchange rates for Pakistan, India and Srilanka, but there are notable short-run interactions between stock prices and exchange rate movements.

No co-integration denotes signal of no any forecast element between stock prices and exchange rates, hence no long run forecasts/prediction can be done on the basis of these variables. Therefore, no policy intervention can be made in order to achieve long term results. On the other hand, due to deplete of short run feedback effects between stock price and exchange rate in these countries, it is crucial that policy makers should take into consideration the short run impact of shocks to stock prices and exchange rate. The finding that stock prices Granger et al. (1998) Granger-cause exchange rates in case of Pakistan and there is uni-directional causal association that flows from exchange rate to stock price in case of Srilanka but there is no proof of causality running in either direction in case of India have important policy implications.

As current study uses bivariate approach to test relationship between stock prices and exchange rate. Multivariate approach can also be used including variables such as money supply, oil prices, interest rate and industrial production index in order to provide the new insights and useful results about this relationship.

\section{Reference}

Aggarwal, R. (2003). Exchange rates and stock prices: A study of the US capital markets under floating exchange rates.

Ahmed, W. (2015). Determining the relation of stock prices and exchange rates a study on SAARC countries. International Journal of Current Research, 7(3), 1416514168.

Aydemir, O., \& Demirhan, E. (2009). The relationship between stock prices and exchange rates evidence from Turkey. International Research Journal of Finance and Economics, 23(2), 207-215.

Bahmani-Oskooee, M., \& Sohrabian, A. (1992). Stock prices and the effective exchange rate of the dollar. Applied Economics, 24(4), 459-464.

SIJMB | P-ISSN: 2313-1217 E-ISSN: 2410-1885 @ 201694 Sukkur Institute of Business Administration V.3, No.1 | Apr 16 
Sumaira et al. / Co-Integration between Stock Prices and Exchange Rate of Selected SAARC Countries - An Empirical Study

Brooks, C. (2008). RATS Handbook to accompany introductory econometrics for finance. Cambridge Books.

Devanthran, H. (2009). Interdependence of SAARC-7 countries: an empirical study of business cycles: University Library of Munich, Germany.

Dornbusch, R., \& Fischer, S. (1980). Exchange rates and the current account. The American Economic Review, 70(5), 960-971.

Franck, P., \& Young, A. (1972). Stock price reaction of multinational firms to exchange realignments. Financial Management, 66-73.

Frankel, J. (1983). Monetary and portfolio-balance models of exchange rate determination, in: Jagdeep SB and Bluford HP, eds., Economic interdependence and flexible exchange rates (MIT Press, Cambridge, MA).

Gan, C., Lee, M., Yong, H. H. A., \& Zhang, J. (2006). Macroeconomic variables and stock market interactions: New Zealand evidence. Investment Management and Financial Innovations, 3(4), 89-101.

Gavin, M. (1989). The stock market and exchange rate dynamics. Journal of International Money and Finance, 8(2), 181-200.

Ghartey, E. E. (1998). Monetary dynamics in Ghana: evidence from cointegration, error correction modelling, and exogeneity. Journal of Development Economics, 57(2), 473-486.

Giovannini, A., \& Jorion, P. (1987). Interest rates and risk premia in the stock market and in the foreign exchange market. Journal of International Money and Finance, 6(1), 107-123.

Granger, C. W., Huang, B.-N., \& Yang, C. W. (1998). A bivariate causality between stock prices and exchange rates: Evidence from recent asia flu. Department of Economics, UCSD.

Halttunen, Masson, \& Branson, W. H. (1977). Exchange rates in the short run: The dollar-dentschemark rate. European Economic Review, 10(3), 303-324.

Hasan, Javed, \& Tariq, M. (2009). An empirical investigation of the causal relationship among monetary variables and equity market returns.

Ibrahim, M. (2003). Macroeconomic forces and capital market integration A VAR analysis for Malaysia. Journal of the Asia Pacific Economy, 8(1), 19-40.

Issahaku, \& Haruna. (2013). Macro-economic Variables and Stock Market Returns in Ghana: Any Causal Link. Asian economic and financial review, 3(8), 10441062.

Johannisson, B. (1991). University training for entrepreneurship: Swedish approaches. Entrepreneurship \& Regional Development, 3(1), 67-82.

Johansen, S., \& Juselius, K. (1990). Maximum likelihood estimation and inference on cointegration - with applications to the demand for money. Oxford Bulletin of Economics and statistics, 52(2), 169-210.

Lee, C.-H., Doong, S.-C., \& Chou, P.-I. (2011). Dynamic correlation between stock prices and exchange rates. Applied financial economics, 21(11), 789-800.

Meese, Rogoff, \& Kenneth. (1983). Empirical exchange rate models of the seventies: Do they fit out of sample? Journal of international economics, 14(1), 3-24.

SIJMB | P-ISSN: 2313-1217 E-ISSN: 2410-1885 @ 201695 Sukkur Institute of Business Administration V.3, No.1 | Apr 16 
Sumaira et al. / Co-Integration between Stock Prices and Exchange Rate of Selected SAARC Countries - An Empirical Study

Muhammad, \& Suleman. (2014). Macroeconomic Variables \& Its Impact On Kse-100 Index. Universal Journal Of Accounting And Finance, 2(2), 33-39.

Muhammad, N., Rasheed, A., \& Husain, F. (2002). Stock Prices and Exchange Rates: Are they Related? Evidence from South Asian Countries [with Comments]. The Pakistan Development Review, 535-550.

Okoli, M. N. (2012). Return-volatility interactions in the nigerian stock market. Asian Economic and Financial Review, 2(2), 389.

Pan, M.-S., Fok, R. C.-W., \& Liu, Y. A. (2007). Dynamic linkages between exchange rates and stock prices: Evidence from East Asian markets. International Review of Economics \& Finance, 16(4), 503-520.

Pesaran, H. H., \& Shin, Y. (1998). Generalized impulse response analysis in linear multivariate models. Economics letters, 58(1), 17-29.

Phylaktis, K., \& Ravazzolo, F. (2005). Stock prices and exchange rate dynamics. Journal of International Money and Finance, 24(7), 1031-1053.

Smyth, R., \& Nandha, M. (2003). Bivariate causality between exchange rates and stock prices in South Asia. Applied Economics Letters, 10(11), 699-704.

Soenen, L. A., \& Hennigar, E. S. (1988). An analysis of exchange-rates and stockprices-the united-states experience between 1980 and 1986. Akron Business and Economic Review, 19(4), 7-16.

Tourani-Rad, A., Liu, M.-H., \& Shrestha, K. M. (2008). Analysis of the long-term relationship between macro-economic variables and the Chinese stock market using heteroscedastic cointegration. Managerial Finance, 34(11), 744-755.

Umer, U. M., Sevil, G., \& Kamiş̧li, S. The Dynamic Linkages between Exchange Rates and Stock Prices: Evidence from Emerging Markets.

Umoru, D., \& Asekome, M. O. (2013). Stock Prices and Exchange Rate Variability in Nigeria Econometric Analysis of the Evidence. European Scientific Journal, $9(25)$.

Yang, Z., Tu, A. H., \& Zeng, Y. (2014). Dynamic linkages between Asian stock prices and exchange rates: new evidence from causality in quantiles. Applied Economics, 46(11), 1184-1201.

Yau, H.-Y., \& Nieh, C.-C. (2006). Interrelationships among stock prices of Taiwan and Japan and NTD/Yen exchange rate. Journal of Asian Economics, 17(3), 535552.

SIJMB | P-ISSN: 2313-1217 E-ISSN: 2410-1885 @ 201696 Sukkur Institute of Business Administration V.3, No.1 | Apr 16 
Sumaira et al. / Co-Integration between Stock Prices and Exchange Rate of Selected SAARC Countries - An Empirical Study

\section{Appendix}

\section{Appendix 1.}
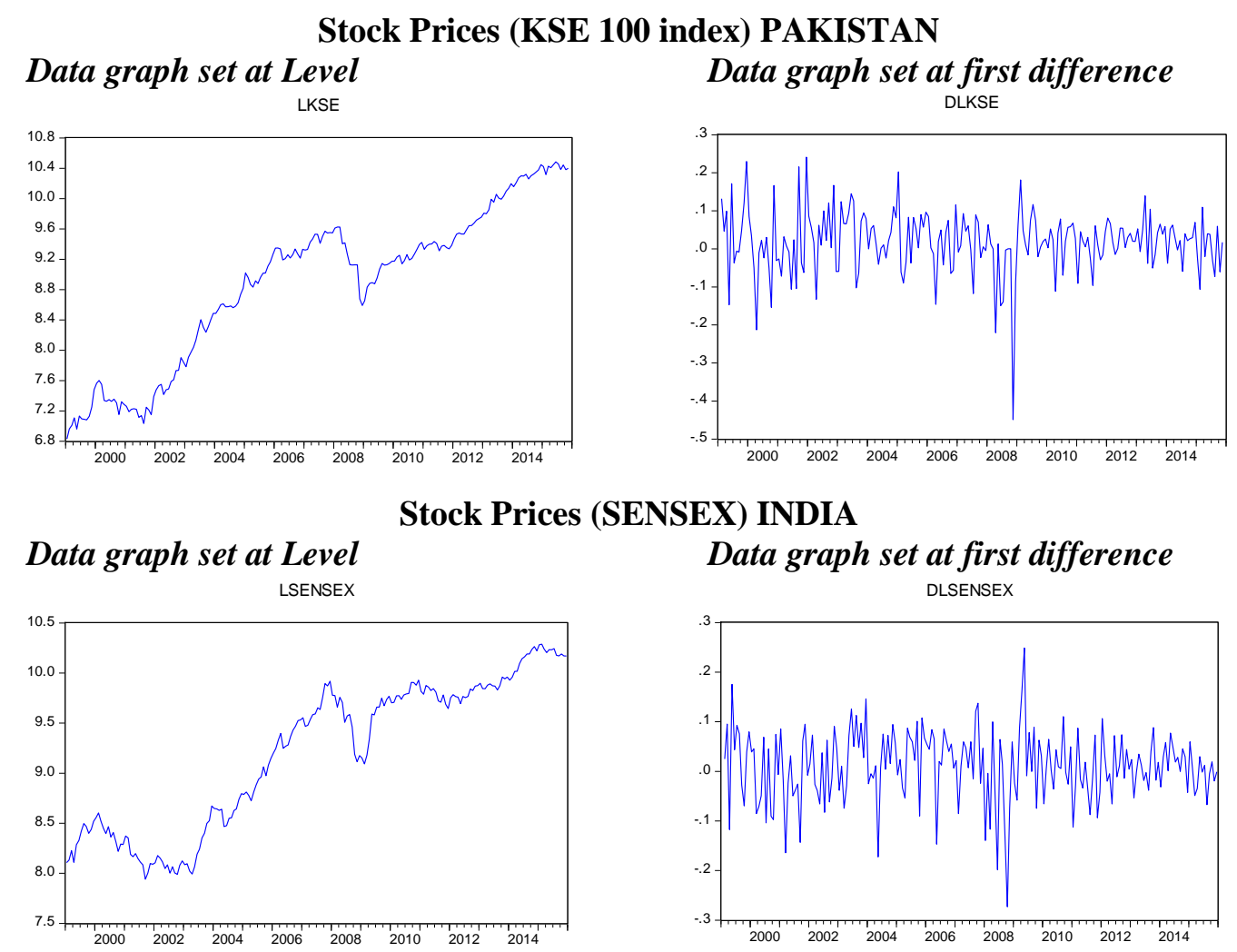

\section{Stock Prices (CSE) SRILANKA}

Data graph set at Level

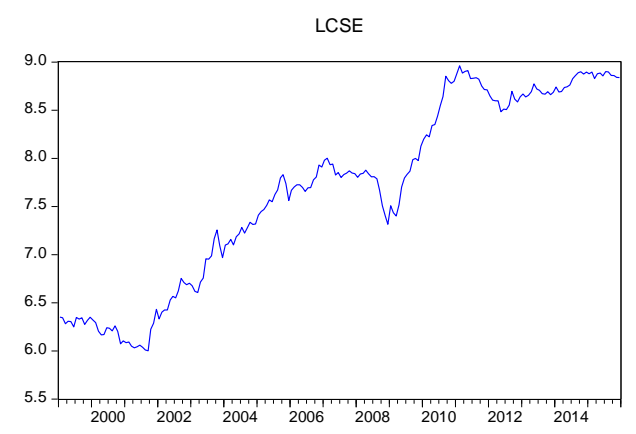

Data graph set at first difference

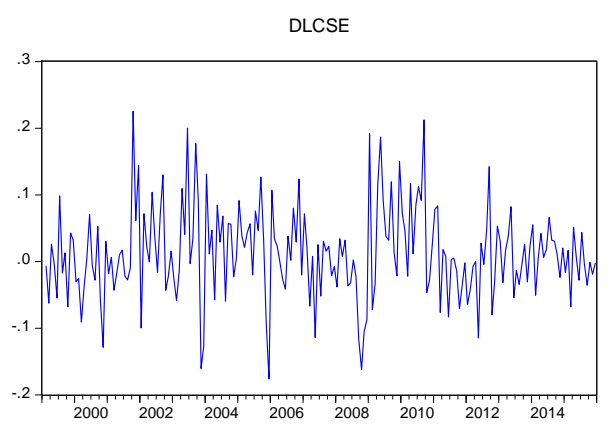

SIJMB | P-ISSN: 2313-1217 E-ISSN: 2410-1885 @ 201697 Sukkur Institute of Business Administration V.3, No.1 | Apr 16 
Sumaira et al. / Co-Integration between Stock Prices and Exchange Rate of Selected SAARC Countries - An Empirical Study

Data graph set at Level

\section{Exchange Rate (ER) PAKISTAN}

LERPKR

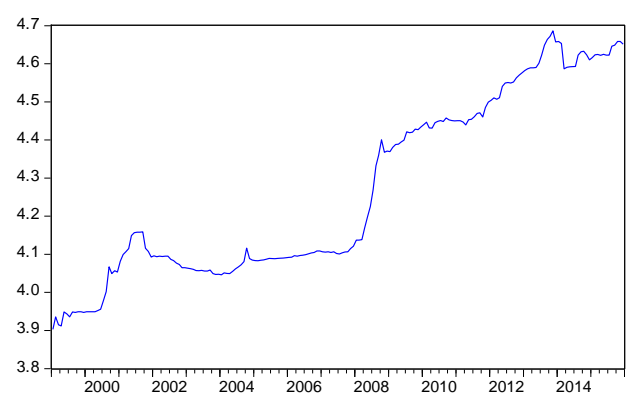

Data graph set at first difference

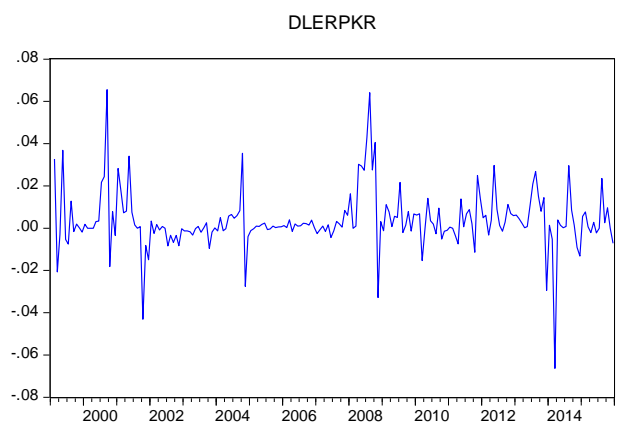

Data graph set at Level

\section{Exchange Rate (ER) INDIA}

\section{LERIND}

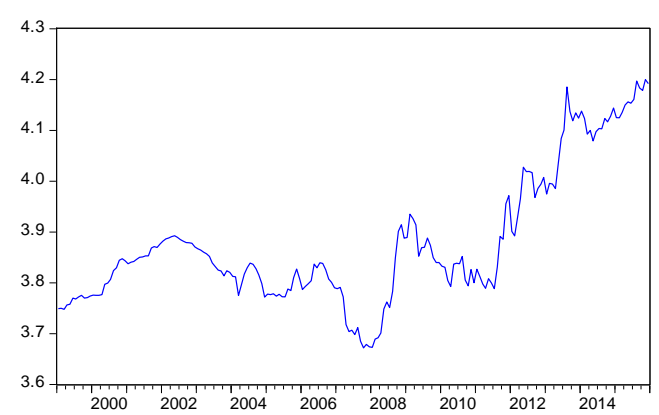

Data graph set at first difference

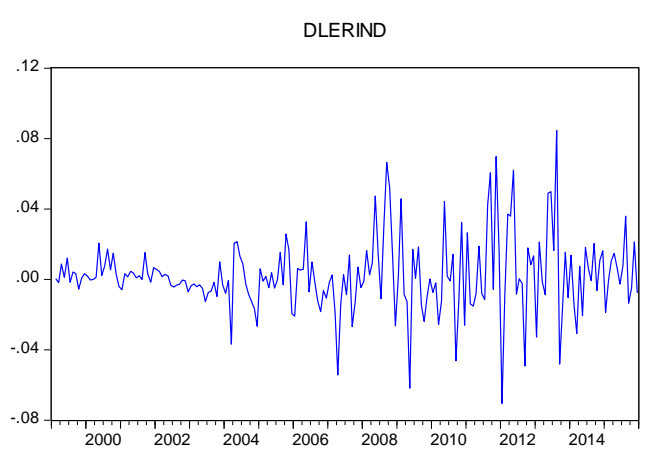

\section{Exchange Rate (ER) SRI LANKA}

\section{Data graph set at Level}

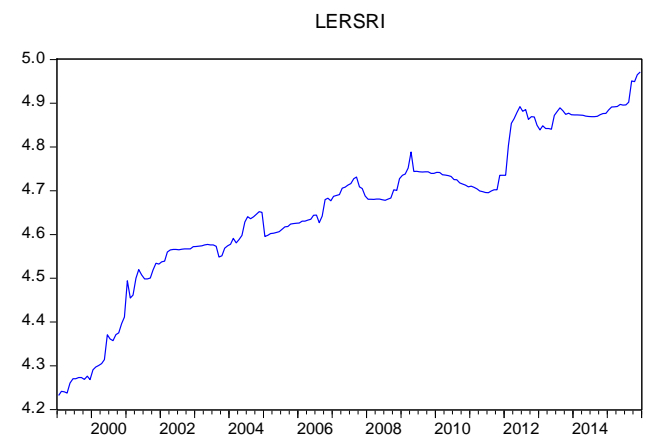

Data graph set at first difference

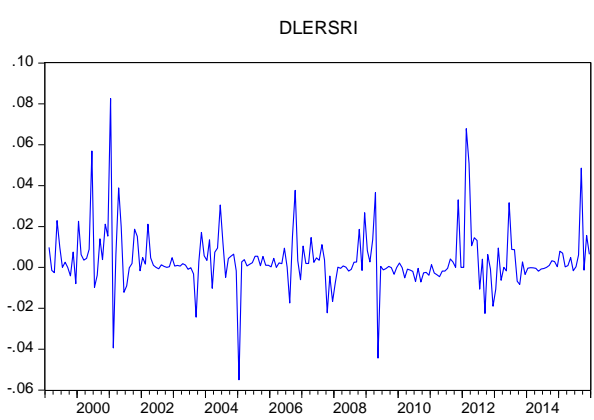

